\title{
Transactions of the Royal Asiatic Society of Great Britain and Ireland
}

http://journals.cambridge.org/TRA

Additional services for Transactions of the Royal Asiatic Society of Great Britain and Ireland:

Email alerts: $\underline{\text { Click here }}$

Subscriptions: Click here

Commercial reprints: $\underline{\text { Click here }}$

Terms of use : $\underline{\text { Click here }}$

\section{On the Hindú Quadrature of the Circle, and the infinite Series of the proportion of the circumference to the diameter exhibited in the four S'ástras, the Tantra Sangraham, Yucti Bháshá, Carana Padhati, and Sadratnamála}

Charles M. Whish

Transactions of the Royal Asiatic Society of Great Britain and Ireland / Volume 3 / Issue 03 / July 1834, pp 509 523

DOI: 10.1017/S0950473700001221, Published online: 24 September 2009

Link to this article: http://journals.cambridge.org/abstract_S0950473700001221

How to cite this article:

Charles M. Whish (1834). XXXIII. On the Hindú Quadrature of the Circle, and the infinite Series of the proportion of the circumference to the diameter exhibited in the four S'ástras, the Tantra Sangraham, Yucti Bháshá, Carana Padhati, and Sadratnamála. Transactions of the Royal Asiatic Society of Great Britain and Ireland, 3, pp 509-523 doi:10.1017/S0950473700001221

Request Permissions : $\underline{\text { Click here }}$ 
XXXIII. On the Hindi Quadrature of the Circle, and the infinite Series of the proportion of the circumference to the diameter exhibited in the four S'ástras, the Tantra Sangraham, Yucti Bháshá, Carana Padhati, and Sadratnamála. By Charles M. Whish, Esq., of the Hon. East-India Company's Civil Service on the Madras Establishment.

(Communicated by the Madras Literary Society and Auxiliary ROYAL A SIATIC SOCIETY.)

Read the 15th of December 1832.

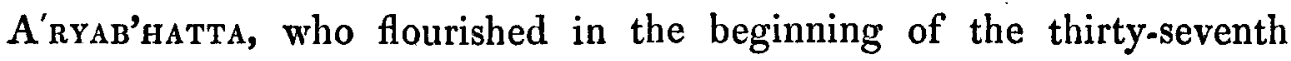
century of the Cáli Yuga,* of which four thousand nine hundred and twenty years have passed, has in his work, the Aryab'hatiyam, in which he mentions the period of his birth, exhibited the proportion of the diameter to the circumference of the circle as 20000 to 62832 , in the following verse :

Chaturadhicam șatamashṭagunandwáshashṭistathá sahasránạm Ayutadwaya vishcambhasyásannó vritta parịáhah. ${ }^{\dagger}$

Which is thus translated :

"The product of one hundred increased by four and multiplied by eight, added to " sixty and two thousands, is the circumference of a circle whose diameter is twice ten " thousand."

The author of the Lilávati, who lived six centuries after A'RYAB'HATTA, states the proportion as 7 to 22 , which, he adds, is sufficiently exact for common purposes. As a more correct or precise circumference, he proposes that the diameter be multiplied by $392 \%$, and the product divided by 1250 ; the quotient will be a very precise circumference. This proportion is the same with that of $A^{\prime}$ 'RYAB'HATta, which is less correct than that of

* Or the sixth century of the Christian era.

+ This verse is in the variety of the Aryavrittam measure, called Vipula.

$3 \mathrm{U} 2$ 
Metius, viz. 113 to 355 , though in all three the circumference is rated at more than the truth. The slóca in the Lilávati is as follows :

Vyásé bhanandagnihaté vibhacté

Chabánasúryaih paridhissussücshmah

Dwávimṣatinighnévihritétha sailaih

Stúlóthavásyádvyavahárayógyah."*

$A^{\prime}$ nyab'hatta has not left behind him any record of the means by which he obtained so accurate a proportion. His work however shews so much geometrical knowledge, that there can be little doubt that he effected his approximation in the same manner with Archimedes, by a numeral calculation of the perimeters of inscribed and circumscribed polygons with the circle; for in the polygon of 768 sides to a circle whose radius is one, the perimeter of the inscribed polygon is 628316 , and of the circumscribed 628326. The circumference of the circle will therefore be greater than 628316, but less than 628326, or nearly half their sum, namely, 628321, to which the above approximation is nearly similar.

In the Súrya Sid'dhánta, the radius of a circle is stated at 3438 , in terms of minutes of the circumference, being about one-quarter of a minute too great; and in the following slóca, it appears that a very coarse rule is laid down by the author.

\section{Yojanánám șatányashṭau bhúkarnó dwigunánitu}

Jadvargató dașagunát padam bhüparidhirbhavét. $†$

"Square the yojanas of the earth's diameter 1600, and multiply the square by 10 , " and extract the root of the product: the root is the equatorial circumference of the " earth."

In such a matter, the strictest accuracy need not be required; but for a general rule, this would err considerably from the truth, being less correct than the proportion of 7 to 22 ; and yet we find the same in the Cámadogdhri, a commentary on the Súrya Sid'dhánta, laid down in the following terms :

Vritta vargát dașa hritat padamvyásóbhavédiha

Evam paricshitóvyásah vrittastu viparitatah.

" The root of the square of the circumference divided by ten, is the diameter; to find the circumference of a given diameter, reverse the rule."

* This verse is in the Upajaitivrittam measure.

+ This verse is in the Anushtubvrittam measure. 
In the sástra named Tántra Sangraha, we find the following lines :

Ishṭa vyásé haté nágavédavahnyabdhichéndubhih

Tithyașwivibudhairbhacté susúcshmah paridhirbhavét

Paridhérvyatyayáchaivamsusícshmam vyasamánayét

Tithyașivibudhairnighnát chachatancéndunétratah

Súcshmó vyásóhi védagni critóbhréndu hritóthava

Trișaghna chacra liptábhyó vyásórtthéshwagnibhirhritéh.

Which are thus translated :

" Multiply any given diameter by 104348, and divide the product by 33215 ; the " quotient is a very correct circumference. To find the diameter, if the circumference " be given, reverse the above numbers. If then you multiply the astronomical circum" ference by 33215, and divide the product by 104348, you will have the diameter in " terms of minutes of the periphery ; or it will be sufficiently exact if you multiply " the circumference by 113, and divide by 355, for a diameter."

The astronomer's circle, anantapura or " the universe," and chachatancendunetram, is; according to alphabetical notation and symbols respectively, 21600, that is, the terms of the minutes in the circumference of twelve signs, containing each thirty degrees. In the first proportion of 33215 to 104.348, if the diameter of a circle be 1 , the circumference will be 3.141592653921, \&c., which is an excellent approximation, being correct to the ninth place of decimals, the tenth being too large; the second proportion, 113 to 355, that of Metius, is a very useful one, being as 1 to 3.1415929, \&c., correct to the sixth place of decimals, the seventh being rather more than the truth.

In another work, named Carana-Padhati, and in one called Sadratnamála, are the two following verses; the first is from the former work :

\section{Anúnanutnánananunnanutyaih \\ Samáhataṣchacra kálávibhactah \\ Chandámșuchandrádhama cumbhipálaih \\ Vyásastadardhantribhamaurvicásyát.}

"If the circumference of a circle in minutes be multiplied by 10000000000 , and the " product be divided by 31415926536 , the quotient will be the diameter of the circle " in terms of the minutes of the circumference, and its half will be the radius."

In the latter work is the subjoined verse:

Evanchátra parárdha vistritimahá vrittasya nahocsharaih Syádbhadrámbudhi sidha janma ganitasradásmayadbhápủgih. 
"If you proceed thus (as laid down in the former verse), and measure the circum"ference of a great circle by 100000000000000000 parts, the circumference will be " equal to 314159265358979324 of such parts."

The approximations to the true value of the circumference with a given diameter, exhibited in these three works, are so wonderfully correct, that European mathematicians, who seek for such proportion in the doctrine of fluxions, or in the more tedious continual bisection of an arc, will wonder by what means the Hindú has been able to extend the proportion to so great a length. Some quotations which I shall make from these three books, will shew that a system of fluxions peculiar to their authors alone among Hindús, has been followed by them in establishing their quadratures of the circle; and a few more verses, which I shall hereafter treat of and explain, will prove, that by the same mode also, the sines, cosines, \&c. are found with the greatest accuracy.

I proceed to quote extracts from the Tántra Sangraham. The first, of the measure called $A^{\prime}$ nushtuborittam, is from the chapter upon sines, \&c.

Vyásárdham prathamannitwatatóványátgunannayét

Sambandhanniyamanchaivam vynéyóvyása vrittayóh.

"Having found the radius, you may construct the sines; but you must first know the "proportion between the diameter and the circumference."

The next is of the Gitivrittam measure :

Vyásé varidhinihité rúpa hrité vyásaságarábhihate

Triṣarádhi vishama sanchyá bhactamṛinamswam prithacramát curyát

Yatsanchyayátra harané critérnivrittá hritistujámitayá

Tasyá úrdhwa gatáyássamasanchyá taddalamgunóntésyát.

Jadvarggó rúpayutó háró vyásábdhighátacah prágwat.

Tabhyámáptam swamriné critédhané șódhananchacaraniyám

Súcshmah paridhissasyát bahucritwóharaṇatóti sủcshmascha.

"Multiply the diameter by 4, and from it subtract and add alternately the quotients " obtained by dividing four times the diameter by the odd numbers $3,5,7,9,11, \& c$., " do thus to the extent required; and having fixed a limit, take half the even number " next less than the last odd divisor for a multiplier, and its square plus one for a divisor. "Multiply four times the diameter by the multiplier, and divide the product by the " divisor, and add it or subtract it, according to the sign of the last quote in the series, " from the sum of the series thus the circumference of the given diameter will be " obtained very correctly." 
If we proceed according to the rule, we have an infinite series of the following form :

$$
C=4 d-\frac{4 d}{3}+\frac{4 d}{5}-\frac{4 d}{7}+\frac{4 d}{9}-\frac{4 d}{11}+\& \mathrm{c} . \pm \frac{4 d \times \frac{1}{2} p}{p^{2}+1}
$$

where $\mathrm{C}=$ circumference, $d$ diameter, and $p$ the last odd divisor diminished by unity. When $d=1$ the series becomes

$$
c=4 \times\left(1-\frac{1}{3}+\frac{1}{5}-\frac{1}{7}+\frac{1}{9}-\frac{1}{11}+\& c \cdot \frac{\frac{1}{2} p}{p^{2}+1}\right)
$$

Then follows a verse of the Gitirrittam measure, explaining more fully the correction by which this series is brought to greater perfection.

Asmat sucshmatarónyó vilichyatécaschanápí samscárah

Anté samasanchyá dala varyassaicó gunassá éva punah

Yuga gunitó rúpayuttassamasancyá dala ható bhavéddhárah

Trișarádi vishama sanchyá haranát paramé tadéva vácáryam.

"I now shew how the correction may be made more complete than in the former "r rule: take the even figure next greater than the last odd divisor in the series $4 \times$ " $\left(1-\frac{1}{3}+\frac{1}{5}-\& c\right.$. $)$ that may have been fixed upon, and square its half, and increase " it by unity; this is to be a multiplier : this multiplier multiply by 4 , and the product " increased by unity multiply by half the original even figure; this last product will be " a divisor : add to the result of the series the quotient of four times the diameter " multiplied by the new multiplier, and divided by the new divisor; the sum will be a " more correct circumference."

The series by means of this correction becomes :

$$
C=4 \times\left(1-\frac{1}{3}+\frac{1}{5}-\frac{1}{7}+\frac{1}{9}-\frac{1}{11}+\& c . \pm \frac{\frac{p^{2}}{4}+1}{\left(p^{2}+4+1\right) \frac{p}{2}}\right)
$$

$p$ being here the last odd divisor increased by unity.

The author being aware how slowly the series converges, found it necessary to correct the last quote, which is done very correctly by the rule he has exhibited.

Next follows a verse of the Anushtubvittam measure.

Vyásavargádravihatat padamsyát prathamam phalam Jatastattat phaláchchápiyávadișchántribhirharét Rupádyayugmasancyábhirllabdéshwéshuyathácramam Vishamánám yutétyacté yugmayógé vẹitisbhavét. 
"Multiply any given diameter squared by 12, and extract the root of the product ; "this is the first quote : divide this first by 3 for the second quote; this second, and each " so obtained quote, divide by 3 continually, place them in order, and divide them in " succession by the odd numbers 1, 3, 5, 7, 9, 11, \&c. Then add together the first, " third, fifth, \&c., quotes ; and add together also the second, fourth, sixth, \&c. quotes ; " then subtract the sum of the even from that of the odd, and the remainder will be the " circumference of the circle, whose diameter was given."

The series laid down in the verse is thus expressed algebraically:

$$
C=\sqrt{ } 12 \times\left(1-\frac{1}{3.3}+\frac{1}{5.3^{2}}-\frac{1}{7.3^{3}}+\frac{1}{9.3^{4}}-\frac{1}{11.3^{3}}+\& \mathrm{c} .\right)
$$

The next verse is of the Gitivrittam measure:

Samapancháhatayóyá rupádyayujás chaturghna múlayutáh. Tabhisshơdașa gunitádvyását prithagá hrịtétu vishamayaté.

Sama phala yágé tyacté syátishṭa vyása sambhavah paridhih.

" Divide the diameter multiplied by 16 severally by the fifth power of the odd " numbers $1,3,5,7,9$, \&c., adding to each fifth power four times its root; of the " quotes thus obtained subtract the sum of the second, fourth, sixth, \&c. from that of " the first, third, fifth, and seventh, the remainder will be the circumference of the circle " whose diameter was taken."

This is an infinite series of the following form :

$$
C=\frac{16 d}{1^{5}+4.1}-\frac{16 d}{3^{5}+4.3}+\frac{16 d}{5^{5}+4.5}-\frac{16 d}{7^{5}+4.7}+\frac{16 d}{9^{5}+4.9}-8 c .
$$

Or, if the diameter be one :

$$
C=16 \times\left(\frac{1}{1^{5}+4.1}-\frac{1}{3^{5}+4.3}+\frac{1}{5^{5}+4.5}-\frac{1}{7^{5}+4.7}+\& c .\right)
$$

The next verse of the Gitiorittam measure is as follows:

Vyásádwaridhi nihatát pritagâptantryáyugvimúld ghanaih

Trighna vyásé swamrịnam cramasah kritwápi paridhivánéyah.

" Divide four times the given diameter by the cubes of the odd numbers $3,5,7,9$, " 11, 13, \&c., subtracting from each its respective root; the quotes thus obtained " alternately add to, and subtract from three times the diameter; this is the circumfe" rence of the circle whose diameter was given."

This is an infinite series (given in the Carana Padhati in nearly the same words), as follows :

$$
C=3 d+\frac{4 d}{3^{3}-3}-\frac{4 d}{5^{3}-5}+\frac{4 d}{7^{3}-7}-\frac{4 d}{9^{3}-9}+\delta c .
$$


Which, if $\mathrm{d}=1$, will be :

$$
C=3+4 \times\left(\frac{1}{2.3 .4}-\frac{1}{4.5 .6}+\frac{1}{6.7 .8}-\frac{1}{8.9 .10}+\& c .\right)
$$

The author then proceeds in the same measure :

Dwyádiyujám vacritayó vyécá hárádwinighna vishcambhe

Dhanamrinamanténtyórdhwa gataujacritidwi sahitáharódwighni.

"Multiply the diameter by 4, and divide the product severally by the squares of the " numbers $2,4,6,8,10$, \&c., subtracting 1 from each square : the quotients alternately " add to, and subtract from, twice the diameter : rectify the şum obtained, by taking the " next odd number less than the last even figure squared, squaring it, adding 2 to the " square, doubling this sum, and with this thus obtained as a divisor, dividing four times

" the diameter : this quotient add or subtract, as is required, from the sum formerly " obtained, for a very correct circumference."

The series thus obtained is :

$$
C=2 d+\frac{4 d}{2^{2}-1}-\frac{4 d}{4^{2}-1}+\frac{4 d}{6^{2}-1}-\frac{4 d}{8^{2}-1}+\& \mathrm{c} . \frac{ \pm d}{\left.\overline{p-1}\right|^{2}+2 \times 2}
$$

Where $\mathrm{C}=$ circumference, $\mathrm{d}=$ diameter, and $\mathrm{p}=$ the last even number squared in the series, which, if the diameter be 1 , becomes,

$$
C=2+4 \times\left(\frac{1}{1.3}-\frac{1}{3.5}+\frac{1}{5.7}-\frac{1}{7.9}+\& \mathrm{c} . \frac{1}{\left.\overline{p-1}\right|^{2}+2 \times 2}\right)
$$

This series, viz. $\frac{1}{1.3}-\frac{1}{3.5}+\frac{1}{5.7}-\frac{1}{7.9}+\& c$. can easily be proved to be equal to the arc of $90^{\circ}-\frac{1}{2}$, therefore $2+4$ into the series will equal the whole circumference, the diameter being one, as in our author's series.

Two other series are then exhibited in lines of the Gíti measure.

Dwyádéschaturádérva chaturadhicánánniréca vargassyuh

Háráh cunjara gunitá vishcambhaswamati calpitóbhájyah

Phalayutirádyé vrittam bhájyadalam phalavihínamányatra.

"Take the squares of the terms, diminished by 1 , of the two arithmetical progressions " whose first terms are respectively 2 and 4, and ratio of progression 4, for divisors: in " the former series, divide 8 times the diameter by the divisors severally, and the sum of " the quotients is the circumference of the circle; in the latter, subtract from 4 times " the diameter the sum of the quotients of 8 times the diameter divided by the divisors " severally, and the result is the circumference in the second case."

VoL. III.

$3 \mathrm{X}$ 
The two series thus explained are found to be of the following forms :

$$
\begin{aligned}
& C=\frac{8 d}{2^{2}-1}+\frac{8 d}{6^{2}-1}+\frac{8 d}{10^{2}-1}+\frac{8 d}{14^{2}-1}+\frac{8 d}{18^{2}-1}+\& \mathrm{c} . \\
& C=4 d-\left(\frac{8 d}{4^{2}-1}+\frac{8 d}{8^{2}-1}+\frac{8 d}{12^{2}-1}+\frac{8 d}{16^{2}-1}+\& \mathrm{c} .\right)
\end{aligned}
$$

Which, if $d=1$, become respectively :

$$
\begin{array}{r}
C=8 \times\left(\frac{1}{1.3}+\frac{1}{5.7}+\frac{1}{9.11}+\frac{1}{13.15}+\frac{1}{17.19}+\delta c .\right) \\
C=4-8 \times\left(\frac{1}{3.5}+\frac{1}{7.9}+\frac{1}{11.13}+\frac{1}{15.17}+\frac{1}{19.21}+\& c .\right)
\end{array}
$$

Now, let the former series within the brackets be $a$, and the latter $b$; then itcan be easily proved that $a+b$, or the series $\frac{1}{1.3}+\frac{1}{3.5}+\frac{1}{5.7}+\frac{1}{7.9}+\frac{1}{9.11}+\& \mathrm{c} .=\frac{1}{2}$; and it has been mentioned above that the series $\frac{1}{1.3}-\frac{1}{3.5}+\frac{1}{5.7}-\frac{1}{7.9}+\& \mathrm{c} .=$ (when the diameter is one), the arc of $90^{\circ}-\frac{1}{2}=a-b$; having therefore the values of $a-b$ and $a+b$, it can be easily proved that $a=$ the $\operatorname{arc}$ of $45^{\circ}$, and $b=\frac{1}{2}-$ arc of $45^{\circ}$; therefore, in the first of these quadratures, $8 a=$ circumference, and in the second, $4-8 b=$ circumference also, as taught by the author.

The author, after laying down the above series, proceeds to shew in numbers a proportion of the circumference to the diameter in the verse which has been originally quoted and translated, and then finishes his chapter by rules for finding the sines and cosines, of which mention will be made hereafter.

In the Carana Padhati, the sixth chapter commences thus :

Vyásácchaturghnát bahuṣah prithac sthát

Tripanja saptadyayugáhritáni

Vyasé chatuoghné cramașastwrinam swam

Curyáttadásyát paridhissusúcshmah.

" Divide the given diameter multiplied by 4 severally and continually by the odd " numbers $3,5,7,9,11, \& c .$, and the quotients thus obtained, alternately subtract "from, and add to, the diameter multiplied by 4 . The result is the precise circum« ference."

This series is the same with the first laid down by the author of the Tantra Sangraha, namely,

$$
C=4 \times\left(1-\frac{1}{3}+\frac{1}{5}-\frac{1}{7}+\frac{1}{9}-\frac{1}{11}+\& c .\right)
$$


The next verse in the chapter is of the measure called Gitiorittam.

Vyásádwana samgunitát prithagáptantryádyay ugvimúlaghanaih

Irigunita vyásé swamrinam Cramaṣah critwápi paridhiránéyah.

" Divide the given diameter multiplied by 4 severally and continually by the cubes of " the odd numbers $3,5,7,9,11$, \&c., subtracting from each cube its respective "root; the sums thus obtained alternately add to, and subtract from, 3 times the " diameter: thus you will obtain the circumference of the circle whose diameter was "given."

This series is also the same with one of the former book, namely,

$$
C=3+4 \times\left(\frac{1}{2.3 .4}-\frac{1}{4.5 .6}+\frac{1}{6.7 .8}-\frac{1}{8.9 .10}+\& c .\right)
$$

The fourth verse of the chapter is of the measure called Indra Vajravrittam.

\section{Vargairyujámvadwigunairnnirécaih \\ Vargicritairvarjitayugma vargaih \\ Vyásancha shadghnam vibhajét phalam swam \\ Vyásé trinighné paridhistadásyat.}

"Add to three times the diameter the sum of the quotes obtained by dividing six " times the diameter by the square of twice the square minus one of the even numbers “ $2,4,6,8,10$, \&c., subtracting from each the square of its even figure respectively. "The sum is the circumference."

This is an infinite series thus expressed algebraically:

$$
C=3 d+\frac{6 d}{\left(2.2^{2}-1\right)^{2}-2^{2}}+\frac{6 d}{\left(2.4^{2}-1\right)^{2}-4^{2}}+\frac{6 d}{\left(2 \cdot 6^{2}-1\right)^{2}-6^{2}}+\& \mathrm{c} .
$$

Which, if the diameter $=1$, becomes

$$
C=3+6 \times\left(\frac{1}{1.3 .3 .5}+\frac{1}{3.5 .7 .9}+\frac{1}{5.7 .11 .13}+\frac{1}{7.9 .15 .17}+\frac{1}{9.11 .19 .21}+\& c .\right)
$$

The author proceeds with the verse originally quoted, for determining the diameter and radius in terms of minutes of the circumference, and then teaches how, by certain series, the sines, cosines, \&c. are to be constructed. He next exhibits a stanza for finding an arc of the circumference of a circle by means of the sum obtained by multiplying the sine of the arc into its radius and dividing the product by its cosine. This sum, it will be readily observed, is equivalent to a tangent of that arc, for cosine is to radius as sine is to tangent; but the tangent individually does not appear in the mathematics of the Hindus. 
The lines are as follow:

Vyásárdhénahatádabhishṭa gunatah Cótyaptamádyam phalam

Jyávargéna vinighnamádimaphalam tattat phalanchá harél

Crityá cóti gunasya tatratuphaléshwécatripanchí dibhi

Bhuctéshwójayutéstyajét samayutim jivádhanussishtyaté.

"Multiply the given sine by radius, and divide the product by cosine for the first " quote; multiply this quote by the square of the sine, and divide the product by the " square of the cosine for the second quote: multiply and divide this last quote, and so " continually each obtained quote, by the square of the sine and the square of the cosine " respectively, and the quotes obtained by this means divide in succession by the odd " numbers 1, 3, 5, 7, 9, 11, \&c.; then the sum of the 2d, 4th, 6th, 8th, \&c. quotes " being subtracted from the sum of the 1 st, $3 \mathrm{~d}, 5 \mathrm{th}, 7 \mathrm{th}, 9 \mathrm{th}, \& \mathrm{c}$. quotes, the remainder " will be the arc of the sine which was taken."

Note.-If the cosine be less than the sine of the given angle, change the names of the turo, and proceed as laid down in the rule.

The infinite series thus beautifully and concisely expressed in the Sanscrit slóca, is the following:

$$
a=\frac{r \times s}{\cos .}-\frac{r \times s^{3}}{3 \cos .^{3}}+\frac{r \times s^{5}}{5 \cos s^{5}}-\frac{r \times s^{7}}{7 \cos ^{7}}+\frac{r \times s^{9}}{9 \cos .^{9}}-\& \mathrm{c} .
$$

Where $a=\operatorname{arc} ; r=$ radius ; $s=$ sine, and $\cos =$ cosine.

In this series, the first quote equals the tangent of the $\operatorname{arc}=t$; the second quote equals tangent cubed, divided by thrice radius squared; the third equals tangent to the fifth power divided by 5 into radius to the fourth power; or, algebraically, thus:

$$
a=t-\frac{t^{3}}{3 r^{2}}+\frac{t^{5}}{5 r^{4}}-\frac{t^{7}}{7 r^{6}}+\frac{t^{9}}{9 r^{8}}-\& \mathrm{c} .
$$

Which is easily proved to be true by a process in fluxions, which demonstrates the fact that the fluxion of the tangent of an arc is to the fluxion of the arc itself as the square of the secant is to the square of the radius; in which case, the fluxion of the arc is proved to be equal to $\frac{r^{2} t}{r^{2}+t^{2}}$ and if $r^{2} i$ be divided by $r^{2}+t^{2}$, the quotient will be $\dot{t}-\frac{t^{2} \dot{t}}{r^{2}}+\frac{t^{4} \dot{t}}{r^{4}}-\frac{t^{6} \dot{t}}{r^{6}}+\frac{t^{8} \dot{t}}{r^{8}}-\& c \cdot=\dot{a}$; and the fluents of each being taken, it becomes $t-\frac{t^{3}}{3 r^{2}}+\frac{t^{5}}{5 r^{4}}-\frac{t^{7}}{7 r^{6}}+\frac{t^{9}}{9 r^{8}}-\& c .=a=$ the arc itself, as is laid down in the Carana Padhati. 
It is also seen that from this verse the matter is derived of the former series ; for if (in the first series) the arc of $45^{\circ}$ be taken, then the tangent will be equal to radius; and if radius $=1$, the above series becomes $1-\frac{1}{3}+\frac{1}{5}-\frac{1}{7}+\frac{1}{9}-\frac{1}{11}+\& \mathrm{c} .=a$; and four times this sum will be the semicircumference, or when the diameter is 1 , the whole circumference; therefore $4 \times\left(1-\frac{1}{3}+\frac{1}{5}-\frac{1}{7}+\frac{1}{9}-\frac{1}{11}+\& c .,\right)$ the circumference, as shewn in the Tantra Sangraha, and in the Carana Padhati.

I proceed now to quote some verses from the Sadratnamila. The first which I shall extract is from the chapter on sines, and is of the measure called Sálini-vrittam.

Vargádwyásasyárcanighnāt padamyat

Tatryamșó yastécha tattannavámṣáh

Dwigna vyécaicadwi purvaujayugmah

Chinnányaicya dwyantaram vịitanáhah.

"Square the diameter and multiply the product by 12 , and extract the root of this " product ; the root obtained will be the modulus of odd quotes, which if you divide " by 3 , the quotient will be the modulus of even quotes. Divide each modulus " continually by 9 , and the quotient thus obtained from the former, divide by double " the numbers $1,3,5,7,9, \& c$. minus 1 respectively, and the quotient obtained from " the latter, by double the number $2,4,6,8,10, \& \mathrm{c}$. minus 1 respectively, add up the " new obtained quotes, and subtract the sum of those gotten from the even from the " sum of those gotten from the odd modulus, the remainder is the circumference of the " circle."

The next verse of the Sarddula-viccridita measure is this :

Vyasárcaghnacriteh padegnibhiratónitécha tattat phaláh Cháthaicyadyayugá hriteshu paridhirbhédóyugójaicyayóh.

Evanchátra parárdha vistriti mahávrittasya náhácsharaih Syátbhadrámbudhi sidha janma ganitasradhásmayatbhúpagíh.

"Square the diameter and multiply the product by 12, and extract the root of this " product; this root divide continually by 3 , and the quotients thus obtained by 1,3 , " $5,7,9,11$, \&c., and subtract the sum of the $2 \mathrm{~d}, 4 \mathrm{th}, 6 \mathrm{th}, 8 \mathrm{th}$ of the last obtained "quotes from the sum of the $1 \mathrm{st}, 3 \mathrm{~d}, 5 \mathrm{th}, 7 \mathrm{th}, 9 \mathrm{th}, \& \mathrm{c}$. If you do thus, and measure " the diameter of a great circle by 100000000000000000 equal parts, the circumference " will be equal to 314159265358979324 of such parts."

The rule laid down in this verse is exactly similar to that communicated by Dr. Halley to the Royal Society of London; and is founded upon the 
principles laid down in another sloca of the Vasantitilaca-vrittam measure in the same chapter, as follows :

Cotáhrita triguna báhu vadhé chatasmá

Tattat phaláchcha bhujavarga hatáttu cotyáh

Crityá critéshucha dharágni sarádi bhacte

Shwojaicyatastyajatuyugmayutim dhanustat.

"The radius into the sine divided by the cosine is the first quote : this multiplied by " the square of the sine, and divided by the square of the cosine, is the second quote;

" this second, and those obtained continually in the same way, multiply and divide by " the square of the sine and the square of the cosine respectively : divide the quotes in " order by $1,3,5,7,9,11, \& \mathrm{c}$. respectively, and the difference of the sum of the 1st, " 3d, 5th, \&c., and of the 2d, 4th, 6th, \&c., will be the arc whose sine was taken."

This, of which the meaning is the same with that in the Carana Padhati, is expressed thus:

$$
a=\frac{r \times s}{\cos .}-\frac{r \times s^{3}}{3 \cos _{0}^{3}}+\frac{r \times s^{5}}{5 \cos _{0}{ }^{3}}-\frac{r \times s^{7}}{7 \cos ^{7}}+\& \mathrm{c} .
$$

Now if the arc of $30^{\circ}$ be taken, the first quote = the tangent of that arc $=\vee \frac{1}{3}$; to multiply this by the square of the sine, and divide it by the square of the cosine, it is sufficient to divide it simply by 3 (because the square of the sine of $30^{\circ}$ is one-third of the square of the cosine of that angle): divide then each quote in succession by the odd numbers $1,3,5,7$, 9,11 , \&c., respectively ; the arc, thus obtained, multiplied by 6 , will equal the semi-circumference when the radius $=1$, or the whole circumference if the diameter be 1 ; but $6 \times \vee \frac{1}{3}=2 \times \vee 3=\vee 12$; therefore $\vee 12 \times$ $\left(1-\frac{1}{3.3}+\frac{1}{5 \cdot 3^{2}}-\frac{1}{7 \cdot 3^{3}}+\frac{1}{9 \cdot 3^{\ddagger}}-\frac{1}{11 \cdot 3^{5}}+\& c\right.$. ) equals the whole circumference when the diameter is one, according to the rule laid down in the Sadratnamálah in the verse "Vyasírcaghnacriteh," \&c., and in the Tantra Sangraha in the verse "Vyasa Vargadravihatat," \&c. before quoted. The rule also for finding the sum of any arc from the tangent is thus expressed in the same work in four slócas of the Anushtub measure.

Vrittánayana márginábreshita jyáná dhanurnayét

Ishta jyá trijyayórghátát cótyáptam prathamam phalam

Jyá vargom gunacam critwá cotí vargancha hâraeam

Prathamádi phalébhyóthá néyáphalalatirmuhuh.

Ecatryádyája sanchyyábhirbhactéshwétéshwanucramát

Ojánám yutitastyacte yugma yógé dhanurbhavét

Dóh cótyóralpamévéshtam calpaniyamihóditam

Muhuh critépi labd'hinánnanyathávasitirbhavet. 
"According to the genius of the rules which we have laid down for the circumference " of the circle, the arc of any given sine may be found thus : take a given sine multiplied " by radius, and divided by the cosine to the given sine for the first quote; let the square " of the sine be a constant multiplier, and the square of the cosine a constant divisor, " the quotes obtained by multiplying and dividing (by these) the first quote, must be " placed in order one under the other, and divided in succession by the odd numbers 1, 3, " $5,7,9,11, \& c$; ; then subtract the sum of the even from that of the odd quotes, " and the remainder will be the arc whose sine was taken. If the sine of the given are " be greater than its cosine, call that the cosine, and the cosine to it the sine."

Having thus submitted to the inspection of the curious eight different infinite series, extracted from Bráhmanical works for the quadrature of the circle, it will be proper to explain by what steps the Hindú mathematician has been led to these forms, which have only been made known to Europeans through the method of fluxions, the invention of the illustrious Newton. Let us first, however, know the age of these works; and as far as can be determined, the authors. First, then, it is a fact which I have ascertained beyond a doubt, that the invention of infinite series of these forms has originated in Malabar, and is not, even to this day, known to the eastward of the range of Gháts which divides that country, called in the earliest times Céralam, from the countries of Madura, Coimbatore, Mysore, and those in succession, to that northward of these provinces.

The author of the Sadratnamálah is SANCARA VARMa, the younger brother of the present Rájá of Cadattanáda near Tellicherry, a very intelligent man and acute mathematician. This work, which is a complete system of Hindú astronomy, is comprehended in two hundred and eleven verses of different measures, and abounds with fluxional forms and series, to be found in no work of foreign or other Indian countries.

The author of the Carana Padhati, whose grandson is now alive in his seventieth year, was Pathumana Sóma Yaji, a Nambútiri Bráhmana of Tirusívapura (Trichúr) in Malabar. In the first verse of the commentary on his work, he is thus mentioned :

Nutuna griha sama sutarachitayah carana padhatervidusha Bhasham vilichati caschit balanam bhodhanarthamalpadhiyam.

"The Carana Padhati, a path to arithmetic, composed by Nutunagriha Sóma "SUta, I now proceed to explain in the common tongue, to adapt it to the genius of " young scholars." 
Nutunagriha Sóma Súta bears the meaning in Sanscrita of the Malabar terms "Puthamana Sóma Yaji," the first word being the name of his house.

The last verse of his work contains its date in numerical letters in terms of days of the Caliyuga; a mode of dating which, in the country, is to be traced back to upwards of one thousand seven hundred years ago, as may be seen in the inscriptions taken from the pagoda of Tirutunnuir near Calicut. The verse is as follows :

\section{Iti sivapura nam agramajah Capiyajwa \\ Cimapi Carana padhatyahwayam tantra rupam \\ Vyadhita ganita metutsamyagalocyasantah \\ Cathitamihavidantassuntu santosha pantah.}

The words Ganita Metutsamyac, written in numbers, amount to 1765653 in terms of days of the present age; which is found to agree with A.D. 1733, being 86 years and 271 days before the 31 st of December 1819 ; SómA YAJI was not, however, inventor of the system by which he formed his infinite series.

The author of the Tantra Sangraha, who was educated in the college of Bráhmanas at Trichúr (which college still exists, and which is a place of reputed sanctity, and certainly of respectable learning), has, among his works on arithmetic and astronomy, laid the foundation for a complete system of fluxions, and opened a mine of wealth in mathematics to those students who can boast of being his followers, of which they are most eminently jealous. The copy of the work, which $I$ have obtained with some difficulty, by frequent intercourse with this interesting society, bears in itself marks of antiquity, the commentary in the vulgar tongue being written in a language which is not now generally current in Malabar, and the forms of many letters differing materially from those of the present day.

The author of the work is Talaculattúra Nambu'tiri, of Cérala, or Malabar ; the first epithet being the name of his house, the latter the title of his rank : he flourished in the forty-sixth century of the present age, or Caliyuga.

The testimonies as to the author, and the period in which he lived, are the following, viz. The general consent of the learned in Malabar; the date which is shewn in the commencement of the work itself, namely, the year 4600 of the Caliyuga; the mention made of him in the first chapter of a work named Driccaranam by his commentator, the author of the Yucti-Bháshá, Cellalura Nambutiri, in which, while relating the history of the progress of astronomy, from the improvements of $A^{\prime}$ ryaB'HatTa up 
to his own period, he thus observes: "Much difference having occurred " in astronomical calculations, in the year of the Caliyuga 4532 a Bráh" man of high rank who lived on the coast of the western ocean, having " examined the heavens for twelve years, established what is laid down " in the Tantra-Sangraha." This is the evidence of the author of the Yucti-Bháshá, the commentary on the Tantra-Sangraha, concerning the author of the latter work: the date of the Driccaranam is mentioned in the latter part of the work, viz. the $783 \mathrm{~d}$ of the Malabar era; and in the summary account of the periods of astronomy, it is written 4708 of the Caliyuga, both of which coincide with the year 1608 of the Christian era.

A farther account of the Yucti-Bháshá, the demonstrations of the rules for the quadrature of the circle by infinite series, with the series for the sines, cosines, and their demonstrations, will be given in a separate paper: I shall therefore conclude this, by submitting a simple and curious proof of the 47 th proposition of EucLid, extracted from the Yucti-Bháshá. In the accompanying figure, let $\mathrm{ABC}$ be a triangle, having the angle at $\mathrm{C}$ a right angle: on $\mathrm{AC}$ describe the square $A C F N$, and on $B C$ describe the square $\mathrm{BCDE}$ : on $\mathrm{ED}$ take $\mathrm{EG}$ equal to $\mathrm{AC}$, and on $\mathrm{AD}$ take. $\mathrm{AH}$ equal to $\mathrm{BC}$, draw $\mathrm{HK}$ perpendicular to $\mathrm{AD}$ and equal to $\mathrm{AC}$, join $\mathrm{BG}, \mathrm{GK}$, and $\mathrm{AK}$.

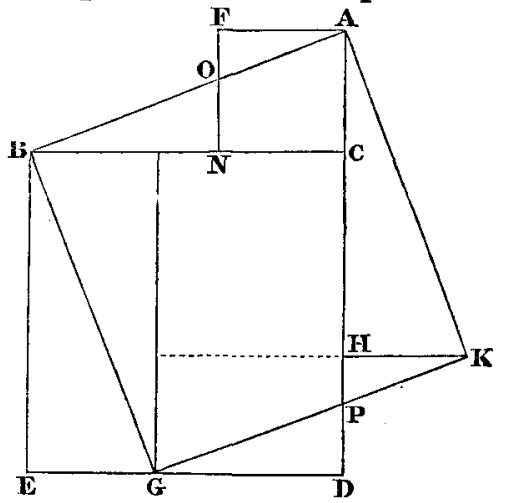

The mathematician will easily prove that the three spaces AFO, PGD, and BEG, parts of the squares SACFN and BCDE not included in the figure $A B G K$, are equal to, and identical with, the spaces $K H P, O B N$, and AHK, not occupied by any parts of the above two squares; id est, that the sum of the two squares ACFN and BCDE equals the figure ABGK; but this, from its construction, is a square, and is drawn upon the hypothenuse ABC. This is probably the form by which Pythagoras discovered the celebrated problem, which EucLID afterwards so beautifully illustrated in the 47 th proposition of the first book of his 'Elements.' 